\title{
Pengelolaan Keuangan Desa: Perencanaan Sampai Dengan Pertanggungjawaban pada Desa di Kecamatan Cilongok Banyumas
}

\author{
1Suwarno \\ Universitas Pancasila, Indonesia
}

\section{N F O A R T I K E L}

JEL Classification:

M41

G18

\section{Keywords:}

management system, control system, village financial, dan regulation

\section{A B S TRACT}

This study aims to analyze the vilages financial management system based on the aspects of planning, implementation, administration, reporting to village financial accountability according to applicable regulations to determine the supporting and obstacles factor in the village financial management. This study taken place at 5 village that is Batuanten, Cipete, Karanglo, Karangtengah, and Pernasidi villege in sub-distric Cilongok, distric Banyumas, West Java Province. This study can be categorized as descriptive qualitative research using case study method. Deep interview and direct observation on village financial management activities are used on this study. The reruslt are showed that generaly village financial management on Cilongok sub-district is good enough, but there is still room on improvement in administration, reporting, and accountability phase. The support from Cilongkok sub-district team, Banyumas district government assist and the performance of village financial management are the supporting factor in good village financial management at Cilongok sub-district. While the limitations of human resource, inadequate of information system, and the incomplete of village financial management regulations are the obstacle factor.

\section{A B S T R A K}

Tujuan penelitian ini adalah untuk menganalisis mekanisme pengelolaan keuangan desa dari aspek perencanaan, pelaksanaan, penatausahaan, pelaporan sampai dengan pertanggungjawaban keuangan desa sesuai regulasi yang berlaku, sehingga dapat diketahui faktor pendukung dan hambatan dalam pengelolaan keuangan desa. Penelitian ini dilakukan pada 5 (lima) desa di Kecamatan Cilongok, Kabupaten Banyumas, Provinsi Jawa Tengah yaitu Desa Batuanten, Desa Cipete, Desa Karanglo, Desa Karangtengah, dan Desa Pernasidi. Penelitian ini dilaksanakan dengan pendekatan kualitatif dengan metode studi kasus. Sumber data yang digunakan adalah data primer, yang dilakukan dengan wawancara secara mendalam dan observasi langsung pada kegiatan pengelolaan keuangan desa. Hasil penelitian menunjukkan bahwa secara umum pengelolaan keuangan desa pada Kecamatan Cilongok sudah cukup baik, meskipun masih terdapat kekurangan terutama pada tahap penatausahaan, pelaporan, dan pertanggungjawaban. Faktor pendukung terciptanya pengelolaan keuangan desa yang baik pada Kecamatan Cilongok antara lain: dukungan tim dari Kecamatan Cilongok, dukungan dari Pemerintah Kabupaten Banyumas, dan kinerja pengelola keuan gan desa. Sedangkan faktor yang menghambat pengelolaan keuangan desa pada Kecamatan Cilongok antara lain: keterbatasan sumber daya manusia, informasi yang belum memadai, dan regulasi terkait pengelolaan keuangan desa yang belum lengkap. 


\section{Pendahuluan}

Desa merupakan salah satu bagian dalam penyelengaraan pemerintahan yang memiliki peran sangat strategis untuk mencapai kesejahteraan masyarakat secara menyeluruh karena desa merupakan bagian dari sistem pemerintahan yang paling dekat dengan masyarakat. Secara khusus, desa memainkan peran penting dalam menyediakan layanan infrastruktur pedesaan dan terlibat dalam kegiatan penurunan kemiskinan, kesejahteraan sosial, pendidikan dasar, dan kesehatan publik (Bastian I, 2015).

Saat ini, kebijakan pembangunan cenderung terpusat di wilayah kota, akibatnya terjadi ketimpangan yang luar biasa antara kota dan desa. Pertumbuhan ekonomi di wilayah kota menyebabkan magnet yang luar biasa bagi masyarakat desa untuk mencari penghidupan yang lebih baik di kota. Tenaga kerja potensial desa yang diharapkan dapat menjadi motor pembangunan desa lebih memilih mencari kehidupan di kota yang dirasa lebih baik. Akibatnya selain kekurangan sumber dana, desa juga kekurangan sumber daya manusia. Kondisi ini semakin memperlambat pembangunan sehingga desa identik dengan infrastruktur yang jelek, sarana prasarana pendidikan dan kesehatan yang minim, kemiskinan, dan berbagai permasalahan kemasyarakatan lainnya.

Mengatasi permasalahan tersebut, Pemerintah mengeluarkan Undang-Undang Nomor 6 Tahun 2014 tentang Desa. Pasal 72 UU Nomor 6 Tahun 2014 dengan jelas mencantumkan salah satu sumber pendapatan desa adalah alokasi dari Anggaran Pendapatan dan Belanja Negara (APBN). Hal ini berarti Pemerintah memiliki kewajiban untuk mengalokasikan secara khusus dana dari APBN untuk desa. Dana tersebut disebut dengan Dana Desa.Sebagai turunan dari Undang-Undang Nomor 6 Tahun 2014 Pemerintah mengeluarkan aturan pelaksanaan antara lain Peraturan Pemerintah Nomor 43 Tahun 2014 tentang Peraturan Pelaksanaan Undang-Undang Nomor 6 Tahun 2014 tentang Desa. Peraturan Pemerintah Nomor 43 Tahun 2014 menyebutkan bahwa Dana Desa adalah dana yang bersumber dari anggaran pendapatan dan belanja negara yang diperuntukkan bagi Desa yang ditransfer melalui anggaran pendapatan dan belanja daerah kabupaten/kota dan digunakan untuk membiayai penyelenggaraan pemerintahan, pelaksanaan pembangunan, pembinaan kemasyarakatan, dan pemberdayaan masyarakat. Selanjutnya besaran Dana Desa ditetapkan dengan Peraturan Pemerintah Nomor 60 Tahun 2014 tentang Dana Desa yang Bersumber dari Anggaran Pendapatan dan Belanja Negara sebagaimana telah diperbarui terakhir dengan Peraturan Pemerintah Nomor 22 Tahun 2015. Sesuai Peraturan Pemerintah Nomor 22 Tahun 2015 alokasi anggaran untuk Dana Desa ditetapkan sebesar $10 \%$ dari dan diluar Dana Transfer ke Daerah dan akan dipenuhi secara bertahap sesuai dengan kemampuan APBN.

Alokasi dana yang cukup besar bagi desa menuntut proses pengelolaan keuangan desa yang baik. Besaran alokasi dana desa tahun 2015 - 2017 sebagai berikut:

Tabel 1

Besaran Alokasi Dana Desa Tahun 2015 - 2017

\begin{tabular}{ccc}
\hline Tahun & $\begin{array}{c}\text { Total } \\
\text { Alokasi } \\
\text { Dana Desa } \\
(\mathrm{Rp})\end{array}$ & $\begin{array}{c}\text { Rata-Rata } \\
\text { Dana Desa } \\
\text { tiap Desa } \\
(\mathrm{Rp})\end{array}$ \\
\hline 2015 & 20,7 triliun & 280 juta \\
2016 & 46,98 triliun & 628 juta \\
2017 & 60 triliun & 800 juta \\
\hline \multicolumn{3}{c}{ Sumber: } \\
& www.djpk.kemenkeu.go.id
\end{tabular}

Pengelolaan keuangan desa selama ini tidak luput dari permasalahan-permasalahan, bahkan tidak sedikit para pengelola keuangan desa yang terjerat kasus hukum, mulai kasus dana Program Nasional Pemberdayaan Masyarakat (PNPM), kasus beras untuk rakyat miskin (Raskin), kasus dana Alokasi Dana Desa (ADD), kasus tanah desa, serta kasus-kasus lainnya.

Komisi Pemberantasan Korupsi (KPK) telah melakukan kajian sistem terhadap pengelolaan keuangan desa, baik Alokasi Dana Desa (ADD) maupun Dana Desa. Kajian ini bermula dengan diberlakukannya Undang-Undang No. 6 Tahun 2014 tentang Desa yang berimplikasi pada disetujuinya anggaran sejumlah $\mathrm{Rp} 20,7$ triliun dalam Anggaran Pendapatan dan Belanja Negara Perubahan (APBNP) 2015 yang akan disalurkan ke 
74.093 desa di seluruh Indonesia. Dari kajian yang dilakukan sejak Januari 2015, KPK menemukan 14 temuan pada empat aspek, yakni aspek regulasi dan kelembagaan, aspek tata laksana, aspek pengawasan, dan aspek sumber daya manusia(www.kpk.go.id). Menurut hasil kajian tersebut terdapat potensi masalah dalam pengelolaan dana desa sebagaimana disebutkan pada tabel berikut.

\section{Tabel 2 Potensi Masalah dalam Pengelolaan Dana di Desa}

\section{Potensi Masalah}

1. Regulasi dan Kelembagaan

a. Belum lengkapnya regulasi dan petunjuk teknis pelaksanaan yang diperlukan dalam pengelolaan keuangan desa.

b. Potensi tumpang tindih kewenangan antara Kementerian Desa dan Ditjen Bina Pemerintahan Desa Kementerian Dalam Negeri.

c. Formula pembagian Dana Desa dalam Perpres 36 Tahun 2015 mengacu pada aturan yang belum ditetapkan dan hanya didasarkan pada aspek pemerataan.

d. Pengaturan pembagian penghasilan tetap bagi perangkat desa dari ADD yang diatur dalam PP No. 43 Tahun 2014 kurang berkeadilan.

e. Kewajiban penyusunan laporan pertanggungjawaban oleh desa tidak efisien.

2. Tata Laksana

a. Kerangka waktu siklus pengelolaan anggaran desa sulit dipatuhi oleh desa.

b. Belum adanya satuan harga baku barang/jasa yang dijadikan acuan bagi desa dalam menyusun APBDesa.

c. APBDesa yang disusun tidak menggambarkan kebutuhan desa.

d. Rencana penggunaan dan pertanggungjawaban APBDesa kurang transparan.

e. Laporan pertanggungjawaban desa belum mengikuti standar dan rawan manipulasi.

3. Pengawasan

a. Pengawasan terhadap pengelolaan keuangan daerah oleh Inspektorat Daerah kurang efektif.

b. Tidak optimalnya saluran pengaduan masyarakat untuk melaporkan kinerja perangkat desa yang mal-administrasi.

c. Ruang lingkup evaluasi dan pengawasan yang dilakukan oleh Camat belum jelas.

4. Sumber Daya Manusia

a. Potensi korupsi/fraud oleh tenaga pendamping akibat kelemahan aparat desa.

Sumber: www.kpk.go.id

\section{Telaah Teori dan Pengembangan Hipotesis Teori Keagenan (Agency Theory)}

Teori keagenan (Agency Theory) merupakan sebuah teori yang menjelaskan hubungan keagenan antara pemilik sumber daya ekonomis (principal) dengan pihak yang mengurus dan mengendalikan penggunaan sumber daya ekonomis tersebut (agent). Menurut Jensen dan Meckling (1976) hubungan keagenan merupakan sebuah kontrak antara seorang atau lebih yang disebut principal yang menunjuk orang atau pihak lainnya yang disebut agent untuk menjalankan layanan sesuai kepentingan principal, yang mencakup pendelegasian beberapa kewewenangan pengambilan keputusan kepada agent.
Pada organisasi sektor publik baik itu pemerintah pusat, pemerintah daerah, maupun pemerintah desa pada dasarnya terdapat hubungan keagenan sehingga dapat dikaji dengan Teori keagenan (Agency Theory). Moe (1984) menjelaskan bahwa di pemerintahan terdapat suatu keterkaitan dalam kesepakatan-kesepakatan principal-agent yang dapat ditelusuri melalui proses anggaran: pemilih-legislatur, legislatur-pemerintah, menteri keuangan-pengguna anggaran, perdana menteribirokrat, dan pejabat-pemberi pelayanan. Hal yang sama dikemukakan juga oleh Gilardi (2001) dan Strom (2000), yang melihat hubungan keagenan sebagai hubungan pendelegasian (chains of delegation), yakni pendelegasian dari masyarakat 
kepada wakilnya di parlemen, dari parlemen kepada pemerintah, dari pemerintah sebagai satu kesatuan kepada seorang menteri, dan dari pemerintah kepada birokrasi. Lebih lanjut Andvig et al. (2001) menjelaskan hubungan tersebut tidaklah selalu mencerminkan hirarki, tetapi dapat saja berupa hubungan pendelegasian.

\section{Pengelolaan Keuangan Desa}

Definisi Keuangan Desa sebagaimana disebutkan dalam Peraturan Menteri Dalam Negeri Nomor 113 Tahun 2014 tentang Pengelolaan Keuangan Desa adalah semua hak dan kewajiban Desa yang dapat dinilai dengan uang serta segala sesuatu berupa uang dan barang yang berhubungan dengan pelaksanaan hak dan kewajiban Desa. Keuangan Desa dikelola berdasarkan asas transparan, akuntabel, partisipasi, serta dilakukan dengan tertib dan disiplin anggaran. Pengelolaan keuangan desa dalam satu tahun anggaran antara lain tercantum dalam Anggaran Pendapatan dan Belanja Desa (APBDesa). Anggaran Pendapatan dan Belanja Desa (APBDesa) adalah rencana keuangan tahunan Pemerintahan Desa. APBDesa terdiri atas: Pendapatan Desa, Belanja Desa, dan Pembiayaan Desa.

Pendapatan Desa adalah semua penerimaan uang melalui rekening desa yang merupakan hak desa dalam 1 (satu) tahun anggaran yang tidak perlu dibayar kembali oleh desa. Pendapatan Desa terdiri atas kelompok: (1) Pendapatan Asli Desa (PADesa), (2) Transfer, dan (3) Pendapatan Lain-lain. Belanja Desa sesuai Permendagri Nomor 113 Tahun 2014 adalah semua pengeluaran dari rekening desa yang merupakan kewajiban desa dalam satu tahun anggaran yang tidak akan diperoleh pembayarannya kembali oleh desa. Belanja desa tersebut digunakan dalam rangka mendanai penyelenggaraan kewenangan desa. Belanja desa diklasifikasikan ke dalam kelompok:

(1) Penyelenggaraan Pemerintahan Desa, (2) Pelaksanaan Pembangunan Desa, (3) Pembinaan Kemasyarakatan Desa, (4) Pemberdayaan Masyarakat Desa, dan (5) Belanja Tak Terduga. Belanja desa terdiri dari jenis belanja pegawai, belanja barang dan jasa, serta belanja modal. Dan Pembiayaan Desa adalah semua penerimaan yang perlu dibayar kembali dan/atau pengeluaran yang akan diterima kembali, baik pada tahun anggaran yang bersangkutan maupun pada tahun-tahun anggaran berikutnya.

Peraturan Menteri Dalam Negeri Nomor 113 Tahun 2014 tentang Pengelolaan Keuangan Desa menyebutkan bahwa pengelolaan keuangan desa adalah keseluruhan kegiatan yang meliputi perencanaan, pelaksanaan, penatausahaan, pelaporan, dan pertanggungjawaban keuangan desa. Dari definisi tersebut maka siklus pengelolaan keuangan desa terdiri dari: (1) perencanaan, (2) pelaksanaan, (3) penatausahaan, (4) pelaporan, dan (5) pertanggungjawaban.

Tahap perencanaan dimulai dari Pemerintah Desa menyusun rencana pembangunan desa sesuai dengan kewenangannya dengan mengacu pada perencanaan pembangunan Kabupaten/Kota. Perencanaan pembangunan desa disusun secara berjangka meliputi: Rencana Pembangunan Jangka Menengah Desa (RPJM Desa) untuk jangka waktu enam tahun, dan Rencana Pembangunan Tahunan Desa atau yang disebut Rencana Kerja Pemerintah Desa (RKP Desa) yang merupakan penjabaran dari RPJM Desa untuk jangka waktu satu tahun. Setelah APBDesa ditetapkan, maka pelaksanaan keuangan desa mengacu pada APBDesa. Kegiatan pelaksanaan keuangan desa meliputi penerimaan dan pengeluaran keuangan desa. Semua penerimaan dan pengeluaran desa dalam rangka pelaksanaan kewenangan desa dilaksanakan melalui rekening kas desa dan harus didukung dengan bukti yang lengkap dan sah. Seluruh kegiatan pelaksanaan keuangan desa harus ditatausahakan. Penatausahaan merupakan serangkaian kegiatan pencatatan setiap transaksi penerimaan dan pengeluaran desa secara tertib ke dalam buku kas umum dan buku pembantu. Penatausahaan dilakukan oleh Bendahara Desa. Bendahara Desa wajib melakukan pencatatan setiap penerimaan dan pengeluaran serta melakukan tutup buku setiap akhir bulan secara tertib dan membuat laporan pertanggungjawaban setiap bulan kepada Kepala Desa paling lambat tanggal 10 bulan berikutnya. (Permendagri 113 Tahun 2014, Pasal 35). Adapun kegiatan pelaporan adalah kegiatan penyampaian laporan Kepala Desa kepada Bupati/Walikota berupa laporan semester pertama, dan laporan semester akhir tahun. Laporan semester pertama disampaikan paling lambat pada akhir bulan Juli tahun berjalan, sedangkan laporan semester akhir 
tahun disampaikan paling lambat akhir bulan Januari tahun berikutnya. (Permendagri 113 Tahun 2014, Pasal 37).Kepala Desa menyampaikan laporan pertanggungjawaban realisasi pelaksanaan APBDesa kepada Bupati/Walikota setiap akhir tahun anggaran. Laporan tersebut terdiri dari pendapatan, belanja, dan pembiayaan yang ditetapkan dengan Peraturan Desa. Peraturan Desa tentang laporan pertanggungjawaban realisasi pelaksanaan APBDesa dilampiri: Format Laporan Pertanggungjawaban Realisasi Pelaksanaan APBDesa Tahun Anggaran berkenaan, Format Laporan Kekayaan Milik Desa per 31 Desember Tahun Anggaran berkenaan, dan Format Laporan Program Pemerintah dan Pemerintah Daerah yang masuk ke desa. (Permendagri 113 Tahun 2014, Pasal 38).

\section{Penelitian Sebelumnya}

Penelitian yang dilakukan oleh Setyoko, 2011 dengan judul Akuntabilitas Administrasi Keuangan Program Alokasi Dana Desa menemukan antara lain Pengelolaan keuangan desa belum berhasil. Sistem dan mekanisme pelaporan keuangan yang telah disusun dengan baik dan rinci oleh pemerintah kabupaten, tidak dapat dilaksanakan dengan baik oleh aparat desa. Kegagalan ini disebabkan oleh rendahnya kemampuan administratif aparat pemerintah desa, tidak adanya sanksi yang tegas, serta masyarakat yang kurang peduli terhadap administrasi keuangan ADD. Putra, 2013 dengan judul Pengelolaan Alokasi Dana Desa Dalam Pemberdayaan Masyarakat Desa (Sudi pada Desa Wonorejo Kecamatan Singosari Kabupaten Malang), secara umum penggunaan ADD berdasarkan sasaran pemberdayaan sudah berjalan dengan baik meskipun dalam berbagai bidang penggunaan ADD masih belum optimal. Azwardi, 2014, Efektifitas Alokasi Dana Desa (ADD) dan Kemiskinan di Provinsi Sumatera Selatan, menemukan bahwa penyaluran dana ADD belum sesuai dengan ketentuan yang berlaku. ADD berpengaruh negative terhadap kemiskinan. Ruksamin, 2014,dengan judul The Obstacles of Implementation of Village Allocation Fund Program in the North Konawe Southeast Sulawesi, menemukan bahwa Implementasi ADD untuk otonomi pemerintah desa sudah berjalan baik.
Namun diperlukan model kebijakan implementasi ADD yang komprehensif sehingga meningkatkan kemampuan pemerintah desa dalam hal perencanaan, implementasi dan pengendalian ADD untuk pembangunan. Sedangkan Riyanto, 2015, dengan judul Akuntabilitas Finansial Dalam Pengelolaan Alokasi Dana Desa (ADD) di Kantor Desa Perangat Selatan Kecamatan Marang kayu Kabupaten Kutai Kertanegara, menemukan bahwa Akuntabilitas Finansial dalam pengelolaan ADD di Kantor Desa Perangat Selatan mulai dari pelaksanaan sampai dengan pencapaian hasilnya dapat dipertanggungjawabkan di depan seluruh apparat Pemerintah Desa, namun belum dapat dipertanggungjawabkan kepada seluruh masyarakat desa.

\section{Metode Penelitian}

Penelitian ini dilaksanakan dengan pendekatan kualitatif. Moleong (2013) mendefinisikan penelitian kualitatif sebagai penelitian yang bermaksud untuk memahami fenomena tentang apa yang dialami oleh subjek penelitian misalnya perilaku, persepsi, motivasi, tindakan, dan lain-lain, secara holistik dan dengan cara mendeskripsikan dalam bentuk kata-kata dan bahasa, pada suatu konteks khusus yang alamiah dan dengan memanfaatkan berbagai metode alamiah. Pendekatan kualitatif dipilih agar dapat mengungkap fenomena yang terjadi secara lebih mendalam, dan dapat mendeskripsikan realita alamiah yang terjadi. Subyek penelitian yang dipilih adalah Desa-desa pada Kecamatan Cilongok, Kabupaten Banyumas, Provinsi Jawa Tengah. Desadesa pada Kecamatan Cilongok dipilih karena Kecamatan Cilongok merupakan wilayah dari Kabupaten Banyumas yang menerima dana desa yang bersumber dari Anggaran Pendapatan dan Belanja Negara (APBN), Pemerintah Kabupaten Banyumas telah melaksanakan sistem akuntansi berbasis akrual pada tahun anggaran 2014 dan memperoleh opini Wajar Tanpa Pengecualian (WTP) dari Badan Pemeriksa Keuangan Republik Indonesia (BPK RI), serta Kecamatan Cilongok merupakan kecamatan yang paling tertib dalam mengelola keuangan desa berdasarkan monitoring dan keterangan dari bagian perbendaharaan DPPKAD Kabupaten Banyumas. Adapun dari 20 (dua puluh) desa pada Kecamatan Cilongok, dipilih sampling penelitian dengan menggunakan 
purposive sampling dengan kriteria: desa sudah membuat perencanaan desa (RKPDesa), menerima dana desa, dan menyampaikan laporan pertanggungjawaban. Berdasarkan kriteria tersebut, dipilih 5 (lima) desa pada Kecamatan Cilongok yaitu : Desa Batuanten, Desa Cipete, Desa Karanglo, Desa Karangtengah, dan Desa Pernasidi.

Teknik pengumpulan data yang digunakan adalah penelusuran data online, analisis dokumen, observasi, dan wawancara. Metode penelusuran data online digunakan untuk memperoleh datadata terkait alokasi dana desa dari Pemerintah Pusat ke Pemerintah Daerah, kasus-kasus pengelolaan keuangan desa, serta regulasi yang mengatur pengelolaan keuangan desa melalui internet dengan mengakses situs-situs lembaga pemerintah terkait maupun media lainnya. Adapun analisis dokumen mulai dari kegiatan memperoleh dokumen fisik seperti dokumen surat, dokumen pertanggungjawaban keuangan desa (APBDes, RAB, SPP, kuitansi, dan sebagainya), laporan pertanggungjawaban, peraturan-peraturan, dan dokumen fisik lainnya terkait pengelolaan keuangan desa di Kecamatan Cilongok untuk selanjutnya dianalisis apakah dokumen tersebut relevan dengan penelitian atau tidak. Metode ini digunakan untuk memperoleh dokumen-dokumen fisik yang cukup untuk mendukung proses penelitian.

Selain memperoleh data melalui penelurusan online maupun dokumenter, peneliti menggunakan metode observasi langsung di desadesa untuk mengamati proses pengelolaan keuangan desa serta wawancara dengan pejabat pengelola keuangan desa untuk memperkuat data yang diperoleh agar lebih valid dan akurat. Penentuan informan dalam penelitian ini adalah dengan cara menentukan key person. Pertimbangan informan penelitian dengan menentukan key person karena dianggap bahwa key person tersebut telah memahami informasi awal tentang objek penelitian maupun informan penelitian. Key person ini adalah tokoh formal atau tokoh informal (Bungin, 2007). Informan yang dijadikan referensi dalam penelitian ini adalah tokoh yang terlibat langsung dalam proses pengelolaan keuangan desa. Informan tersebut terdiri dari unsur Pemerintah Kabupaten Banyumas yang diwakili oleh Pejabat pada Dinas Pendapatan Pengelolaan Keuangan dan Aset Daerah (DPPKAD), Pemerintah Kecamatan meliputi Camat, Sekretaris Camat atau Kepala Seksi Pemberdayaan Masyarakat Desa, dan unsur Pemerintah Desa yang terdiri dari Kepala Desa, Bendahara, Sekretaris Desa, Kepala Seksi dan Badan Permusyawaratan Desa (BPD).

Analisis data dalam penelitian kualitatif dilakukan pada saat pengumpulan data berlangsung, dan setelah selesai pengumpulan data dalam periode tertentu (Sugiyono, 2005).Analisis data yang digunakan dalam penelitian ini adalah metode studi kasus yang termasuk dalam kelompok analisis kinerja dan pengalaman individual serta perilaku institusi. Menurut Yin (2002) ada lima komponen penting dalam desain studi kasus yaitu: (1) pertanyaan-pertanyaan penelitian, (2) proporsi penelitian, (3) unit-unit analisis penelitian, (4) logika yang mengaitkan data dengan proporsi, dan (5) kriteria untuk menginterprestasikan temuan.

Dalam teknik pemeriksaan keabsahan data, peneliti menggunakan teknik triangulasi dengan sumber data dan triangulasi dengan teknik. Triangulasi dengan sumber berarti membandingkan dan mengecek balik derajat kepercayaan suatu informasi yang diperoleh melalui waktu dan alat yang berbeda dalam penelitian kualitatif (Moleong, 2013). Peneliti menguji kredibilitas data dengan mengecek data yang telah diperoleh di lapangan dari beberapa sumber. Kemudian setelah data tersebut dianalisis, akan dihasilkan suatu kesimpulan dengan adanya kesamaan pendapat dari beberapa sumber, baikinforman yang berbeda profesi, maupun informan yang memiliki profesi yang sama. Sementara triangulasi dengan teknik dilakukan dengan cara mengecek data yang diperoleh melalui wawancara dan dokumentasi. Bila dengan dua teknik pengujian kredibilitas data tersebut menghasilkan data yang berbeda-beda, maka peneliti akan melakukan diskusi lebih lanjut dengan sumber data yang bersangkutan atau dengan sumber data yang lain.

\section{Hasil dan Pembahasan}

Data yang diperoleh selama proses wawancara sangat banyak, namun tidak semua data tersebutdibutuhkan dalam penelitian ini. Mereduksi data (datareduction) berarti merangkum, memilih hal-hal yangpokok, memfokuskan pada hal-hal yang penting, dicari tema dan polanya (Sugiyono, 2005). Dalam mereduksi data, peneliti 
akan memfokuskan pada hasil wawancara dari para informan yang telah ditentukan. Namun sebelum data tersebut disajikan (data display), akan direduksi terlebih dahulu dengan cara meringkasdata, mengkategorikan data, mengarahkan data serta membuang data yang tidak relevan agar didapatkesimpulan (conclution).

\section{Perencanaan APBDesa}

Perencanaan APBDesa bukanlah proses yang singkat, tetapi diawali dari penyusunan perencanaan pembangunan desa. Perencanaan pembangunan desa disusun secara berjangka meliputi: (1) Rencana Pembangunan Jangka Menengah Desa (RPJM Desa) jangka waktu 6 tahun, (2) Rencana Pembangunan Tahunan Desa atau Rencana Kerja Pemerintah Desa (RKP Desa) yang merupakan penjabaran dari RPJM Desa untuk jangka waktu 1 tahun. Dari 5 desa pada Kecamatan Cilongok yang diteliti diketahui tahapan perencanaan ini secara umum telah dilaksanakan dengan baik. Sekretaris Desa seluruhnya telah menyusun Rancangan Peraturan Desa tentang APBDesa berdasarkan RKP Desa tahun berkenaan dan disampaikan kepada Kepala Desa. Kepala Desa menyampaikan Rancangan Peraturan Desa tentang APBDesa kepada BPD untuk dibahas dan disepakati bersama. Pembahasan dengan BPD dituangkan dalam Berita Acara Rapat Badan Permusyawaratan Desa (BPD) atau Nota Kesepakatan antara Pemerintah Desa dengan BPD dan hasilnya ditetapkan Keputusan BPD tentang Persetujuan Peraturan Desa tentang APBDesa. Rancangan Peraturan Desa tentang APBDesa yang telah disepakati dengan BPD juga sudah disampaikan melalui camat. Bahkan untuk membantu camat dalam mengevaluasi APBDesa, Bupati Banyumas mengeluarkan Peraturan Bupati Nomor 15 Tahun 2015 tentang Pengelolaan Keuangan Desa, yang antara lain mengatur pembentukan Tim Fasilitasi dan Evaluasi Rancangan Peraturan Desa tentang APBDesa dan Rancangan Peraturan Desa tentang Perubahan APBDesa pada setiap awal tahun dengan Keputusan Camat.

Namun demikian terdapat hal yang perlu ditingkatkan yaitu APBDesa agar disusun berdasarkan hasil pengkajian keadaan desa yang dibahas dalam musyawarah Desa. Kegiatan pengkajian keadaan desa meliputi: (1)Penyelarasan data desa, (2) Penggalian gagasan masyarakat, dan (3) Penyusunan laporan hasil pengkajian keadaan desa. Penyusunan APBDesa untuk desa di Kecamatan Cilongok belum sepenuhnya didukung dengan laporan hasil pengkajian keadaan desa. Kepala Desa Batu Anten (YHS) menjelaskan:

"kami belum tahu desa kami masuk
tipologi desa yang mana sehingga
prioritas penggunaan dana desa belum
berdasarkan tipologi desa secara pasti.
Selain itu dalam merencanakan
penggunaan dana desa kami juga
terbentur dengan peraturan
pemerintah yang lebih tinggi, sebagai
contoh ketentuan prioritas penggunaan
dana desa untuk sarana prasarana
peribadatan dan pendidikan terbentur
terkait aturan pemberian hibah ke
lembaga"

Kondisi penyusunan APBDesa yang belum sepenuhnya sesuai dengan kebutuhan desa sejalan dengan Laporan Hasil Kajian Pengelolaan Keuangan Desa yang diterbitkan oleh Komisi Pemberantasan Korupsi Tahun 2015, halaman 41 antara lain menyebutkan salah satu potensi masalah dalam pengelolaan keuangan desa adalah APBDesa yang disusun tidak menggambarkan kebutuhan desa.

Selain itu, penyusunan APBDesa di Kecamatan Cilongok juga belum memperhatikan batasan waktu. Rancangan Peraturan Desa tentang APBDesa disepakati bersama paling lambat bulan Oktober tahun berjalan. Namun dalam praktiknya untuk APBDesa Tahun 2015 dan 2016 terlambat. APBDesa Tahun 2015 belum selesai sampai dengan Desember Tahun 2015, dan APBDesa Tahun 2016 belum selesai sampai dengan Desember Tahun 2016. Pada saat penelitian, APBDesa Tahun 2017 juga belum selesai sampai dengan Januari 2017. Dari hasil pendalaman kepada perangkat desa dan kecamatan diketahui bahwa hal tersebut disebabkan karena informasi dari Pemerintah Pusat dan Pemerintah Daerah terkait rencana pembangunan di desa tersebut dan besaran anggaran yang akan diperoleh desa terlambat diperoleh oleh desa dan atau keputusannya berubah-ubah. 


\section{Pelaksanaan APBDesa}

Dalam pelaksanaan penerimaan pendapatan, desa di Kecamatan Cilongok yang menjadi obyek penelitian secara umum sudah melaksanakan sesuai dengan ketentuan. Mekanisme penerimaan dilaksanakan melalui rekening kas desa. Rekening kas desa ditetapkan pada Bank Jateng sesuai ketentuan peraturan Bupati Banyumas. Pemungutan penerimaan desa berupa sewa tanah desa dilakukan oleh Bendahara Desa dengan didukung kuitansi/tanda terima dari desa kepada pihak penyewa. Pemerintah Desa juga tidak memungut penerimaan selain yang sudah ditetapkan. Kepala Seksi Pembangunan Kecamatan Cilongok, DN menjelaskan:

"semua desa di wilayah Kecamatan Cilongok sesuai peraturan Bupati Banyumas diwajibkan menggunakan rekening kas desa yang kita tetapkan di Bank BPD (Bank Jateng). Setiap penerimaan wajib segera disetor ke rekening tersebut. Demikian pula untuk penarikan uang dapat dilakukan setelah memperoleh surat pengantar dari Kecamatan."

Terkait penerimaan dari sewa tanah desa Kepala Desa Karanglo, TH menjelaskan:

"salah satu pendapatan Desa Karanglo adalah penerimaan sewa bengkok (tanah desa). Penyewaan tanah desa ini sudah kami buatkan perjanjian, pembayaran di awal melalui bendahara desa selanjutnya disetorkan ke rekening kas desa. Sewa tanah ini biasanya untuk satu tahun atau beberapa kali musim tanah, karena tanah desa kami berupa sawah-sawah yang disewakan kepada petani."

Dalam pelaksanaan penerimaan, pemerintah desa di Kecamatan Cilongok masih belum dapat melakukan konversi ke dalam nilai uang (rupiah) atas penerimaan swadaya, sumbangan yang berupa tenaga atau barang. Bendahara Desa atau petugas yang ditunjuk belum mengetahui cara mengkonversi penerimaan tersebut, karena belum ada petunjuk teknis dari pemerintah khususnya Pemerintah Kabupaten Banyumas maupun Pemerintah Kecamatan Cilongok. Kepala Desa Karanglo, TH menjelaskan:

"Jika ada kegiatan pembangunan yang
melibatkan swadaya atau gotong
royong masyarakat misalkan
pengaspalan jalan, kami terus terang
tidak dapat menghitung berapa nilai
tenaga atau barang sumbangan
masyarakat seperti batu, dan lain-lain
jika diuangkan. Mungkin perlu
petunjuk caranya dari kecamatan atau
dari kabupaten."

Adapun pelaksanaan pengeluaran/belanja desa didahului dengan pembuatan Rencana Anggaran Biaya (RAB) oleh pelaksana kegiatan yaitu Kepala Seksi untuk mengajukan pendanaan. RAB tersebut harus diverifikasi terlebih dahulu oleh Sekretaris Desa untuk selanjutnya disahkan oleh Kepala Desa. Setelah disahkan oleh Kepala Desa, RAB dapat dijadikan dasar bagi pelaksana kegiatan untuk melakukan tindakan pengeluaran atas beban anggaran belanja kegiatan. Selanjutnya pelaksana kegiatan bertanggungjawab terhadap tindakan pengeluaran yang menyebabkan beban anggaran belanja kegiatan dengan mempergunakan buku pembantu kas kegiatan sebagai pertanggungjawaban pelaksanaan kegiatan di desa.

Pelaksanaan pembayaran oleh Bendahara Desa atas pelaksanaan kegiatan secara umum terdapat dua cara yaitu: pembayaran langsung oleh bendahara kepada pihak penerima tanpa melalui uang muka/panjar, dan pembayaran melalui uang muka/panjar yang biasanya diberikan terlebih dahulu kepada pelaksana kegiatan. Pembayaran secara langsung ini biasanya digunakan untuk pengeluaran yang bersifat rutin seperti pembayaran penghasilan tetap dan tunjangan, operasional perkantoran, operasional RT/RW, dan pembayaran langsung kepada pihak ketiga atas pengadaan barang/jasa yang diajukan oleh pelaksana kegiatan. Sedangkan pembayaran melalui uang muka/panjar diawali dengan permintaan uang muka/ panjar dari pelaksana kegiatan dengan mengajukan Surat Pengajuan Panjar Kegiatan kepada Kepala Desa melalui Sekretaris Desa. Pemberian uang muka/panjar ini diatur dengan mekanisme yang 
cukup ketat misalnya batasan uang muka/panjar dengan jumlah tertentu, batas waktu pertanggungjawaban, dan jenis pengeluaran yang dapat dibayarkan dengan uang muka/ panjar.

Untuk mempertanggungjawabkan uang muka/panjar yang diterima pelaksana kegiatan mencatat uang muka/panjar dalam Buku Kas Pembantu Kegiatan yang dibuat sesuai dengan lampiran Permendagri Nomor 113 Tahun 2014. Buku Kas Pembantu Kegiatan dibuat untuk setiap bidang dan kegiatan sesuai yang ditetapkan dalam APBDes berisi informasi penerimaan dan pengeluaran dana, pengembalian ke bendahara, dan saldo kas yang ada di pelaksana kegiatan. Dalam pelaksanaannya para pelaksana kegiatan di desa pada Kecamatan Cilongok belum membuat Buku Kas Pembantu Kegiatan sesuai dengan format lampiran Permendagri Nomor 113 Tahun 2014. Pembukuan baru dilaksanakan di Bendahara Desa. Pelaksana kegiatan hanya membuat catatan penerimaan dan pengeluaran uang dalam bentuk sederhana. Hal ini karena pelaksana kegiatan belum memahami cara membuat Buku Kas Pembantu Kegiatan. Kaur Perencanaan Desa Pernasidi, SI menjelaskan:

"sebagai pelaksana kegiatan kami merasa belum memiliki bekal yang cukup, kami belum tahu cara menyusun $\mathrm{RAB}$ yang baik, termasuk membukukan uang-uang yang diterima dari Bendahara Desa. Kami perlu pelatihan dari cara menyusun RAB dan pembukuan."

Hal senada juga disampaikan Bendahara Desa Karang Tengah, IDP:

"saat ini pembukuan dana ya dilaksanakan di Bendahara. Pelaksana kegiatan paling mencatat biasa sederhana uang masuk, uang keluar, di kertas biasa. Baru saya yang membukukan ke BKU. Saran saya ya perlu ada pelatihan akuntansi pembukuan bagi perangkat desa termasuk bagi para kaur dan bendahara."

Salah satu dokumen yang harus dibuat oleh pelaksana kegiatan untuk mengajukan tagihan pembayaran setelah menyusun RAB dan mengajukan Surat Pengajuan Panjar Kegiatan adalah Surat Permintaan Pembayaran (SPP). Pelaksana kegiatan mengajukan SPP setelah barang dan atau jasa diterima kepada Kepala Desa melalui Sekretaris Desa untuk diverifikasi terlebih dahulu. Pengajuan SPP dari pelaksana kegiatan kepada Kepala Desa terdiri dari: Surat Permintaan Pembayaran (SPP), Pernyataan Tanggung Jawab Belanja, dan lampiran bukti transaksi. Untuk mengendalikan proses pengajuan SPP ini, Pemerintah Kecamatan Cilongok melalui Kasi Pemerintahan dan Kasi Pembangunan sudah melakukan upaya pengendalian yang cukup baik. Setiap tagihan yang diajukan pelaksana kegiatan di masing-masing desa diverifikasi juga oleh petugas kecamatan untuk meminimalisir risiko apabila terdapat Sekretaris Desa yang belum paham cara memverifikasi SPP dari pelaksana kegiatan. Kepala Seksi Pembangunan Kecamatan Cilongok, DN menjelaskan:
"kami dari kecamatan menerapkan aturan seluruh tagihan dari desa harus masuk ke sini untuk diverifikasi sebelum dibayar, untuk membackup apabila ada Sekretaris Desa yang kurang memahami verifikasi sesuai aturan. Di sini kami cek apakah tagihan tersebut boleh dibayar atau tidak, pajaknya sudah benar apa belum, kemudian kami catat dalam buku register SPP tapi masih gabung untuk seluruh desa."

Dengan sistem seperti ini, maka SPP yang diajukan pelaksana kegiatan di desa pada Kecamatan Cilongok menjadi lebih tertib. Pengajuan SPP sesuai dengan RAB, dilampiri dengan SPTB dan bukti transaksi. Format SPP juga sudah sesuai dengan lampiran Permendagri Nomor 113 Tahun 2014. Proses verfikasi yang dilakukan oleh pihak kecamatan juga sudah meliputi hal-hal yang diharuskan dalam Permendagri Nomor 113 Tahun 2014. Kepala Desa menyetujui permintaan pembayaran setelah proses verifikasi, dan Bendahara Desa melakukan pembayaran.

\section{Penatausahaan APBDesa}


Penatausahaan atas transaksi keuangan desa dilakukan oleh Bendahara Desa. Bendahara Desa wajib melakukan pencatatan setiap penerimaan dan pengeluaran menggunakan buku kas umum, buku kas pembantu pajak, dan buku bank. Selanjutnya Bendahara Desa melakukan tutup buku setiap akhir bulan dan menyusun laporan pertanggungjawaban yang disampaikan kepada Kepala Desa paling lambat tanggal 10 bulan berikutnya. Hasil penelitian menunjukkan Bendahara Desa masih kurang tertib dalam melaksanakan penatausahaan pengelolaan keuangan desa. Pencatatan penerimaan dan pengeluaran desa baru dilaksanakan dengan menggunakan buku kas umum. Bendahara Desa juga belum melakukan penutupan pembukuan setiap akhir bulan secara tertib, belum menyampaikan laporan pertanggungjawaban kepada Kepala Desa paling lambat tanggal 10 bulan berikutnya. Format buku kas umum juga belum sesuai dengan lampiran Permendagri Nomor 113 Tahun 2014. Buku kas umum yang diselenggarakan oleh Bendahara Desa baru berisi informasi nomor, tanggal transaksi, uraian, penerimaan, pengeluaran, dan saldo. Ketidaksesuaian tersebut dijelaskan Kepala Desa Karang Lo, TH mengatakan:

"selama ini kami belum ada pelatihan tentang administrasi desa, termasuk administrasi keuangan desa dan pengadministrasian tentang aset desa".

Bendahara Desa Karang Tengah, IDP juga mengatakan:

"kami mencatat penerimaan dan pengeluaran dalam buku kas umum. Kami belum mengetahui cara mencatat buku kas pembantu pajak, atau buku bank. Mungkin perlu pelatihan administrasi bagi seluruh perangkat desa".

\section{Pelaporan APBDesa}

Sesuai Permendagri Nomor 113 Tahun 2014 Kepala Desa wajib menyampaikan laporan realisasi pelaksanaan APBDesa kepada Bupati/Walikota berupa laporan semester pertama dan laporan semester akhir tahun. Laporan tersebut berupa laporan realisasi APBDesa yang disampaikan paling lambat akhir bulan Juli tahun berjalan untuk laporan semester pertama, dan paling lambat akhir bulan Januari tahun berikutnya untuk laporan semester akhir tahun.

Hasil penelitian menunjukkan secara umum desa yang disampel belum tertib dalam menyampaikan laporan realisasi pelaksanaan APBDesa semester pertama maupun semester kedua. Laporan realisasi pelaksanaan APBDesa semester pertama Tahun 2015 dan 2016 belum disampaikan sampai dengan akhir bulan Juli tahun berkenaan atau akhir bulan Januari tahun berikutnya kepada Bupati/Walikota. Sampai dengan akhir Januari 2017 Bendahara Desa masih dalam proses penyusunan laporan realisasi pelaksanaan APBDesa untuk semester kedua Tahun 2017. Laporan realisasi pelaksanaan APBDesa semester pertama Tahun 2015 dan 2016 masingmasing baru disampaikan bulan Oktober Tahun berkenaan.

\section{Pertanggungjawaban APBDesa}

Kepala Desa di Kecamatan Cilongok belum menyampaikan Laporan Pertanggungjawaban Realisasi Pelaksanaan APBDesa secara tepat waktu. Laporan Pertanggungjawaban Realisasi Pelaksanaan APBDesa Tahun 2015 belum disampaikan sampai dengan akhir bulan Januari 2016 dan baru disampaikan di semester pertama (bulan Juni) 2016. Demikian juga untuk Laporan Pertanggungjawaban Realisasi Pelaksanaan APBDesa Tahun 2016 belum disampaikan sampai dengan akhir Januari 2018.

Laporan Pertanggungjawaban Realisasi Pelaksanaan APBDesa kelima desa yang disampel Tahun 2015 dan 2016 sudah ditetapkan dengan Peraturan Desa. Laporan tersebut sudah dilampiri dengan Laporan Pertanggungjawaban Realisasi Pelaksanaan APBDesa. Namun belum dilampiri dengan Laporan Kekayaan Milik Desa per 31 Desember tahun berkenaan, dan Laporan Program Pemerintah dan Pemerintah Daerah yang masuk ke desa.

Pemerintah Desa belum dapat menyusun Laporan Kekayaan Milik Desa. Laporan Kekayaan Milik Desa berisi informasi aset lancar, aset tidak lancar, kewajiban, dan kekayaan bersih milik desa. Kekayaan desa pada 5 desa yang disampel yang seharusnya dapat disajikan pada Laporan 
Kekayaan Milik Desa antara lain: kas desa, piutang sewa tanah desa, persediaan ATK, tanah desa, peralatan dan mesin, gedung dan bangunan, dan sebagainya. Kelima desa yang disampel memiliki tanah desa yang disewakan. Selain itu, desa Karang Lo juga memiliki tempat usaha/kios di pasar yang disewakan. Atas peristiwa tersebut seharusnya desa dapat menyajikan nilai piutang maupun hutang dari sewa tanah tersebut. Pemerintah Desa belum dapat menyajikan kekayaan desa karena pengelola keuangan di desa (Sekretaris Desa s.d. Bendahara Desa) kurang memahami akuntansi untuk menyajikan laporan kekayaan milik desa. Bendahara Desa Karang Tengah, IDP mengakatan:

"kami belum dapat menyajikan laporan kekayaan desa karena kami belum tahu caranya. Kami belum pernah diberikan pelatihan akuntansi cara menyusun laporan kekayaan desa."

Hal yang sama juga disampaikan oleh Kepala Desa Karang Lo, TH:

"personil kami tidak ada yang berlatar belakang pendidikan akuntansi, sehingga kami belum memahami administrasi keuangan desa, cara mengadministrasikan aset desa, dan sebagainya. Saat ini kami belum bisa menyusun laporan kekayaan desa, caranya seperti apa kami tidak tahu. Kalau secara kondisinya desa kami memiliki tempat usaha di pasar yang kami sewakan, tanah desa yang juga kami sewakan secara tahunan. Kami belum pernah tahu cara mencatat utang maupun piutangnya."

Permasalahan pertanggungjawaban Pertanggungjawaban $\begin{array}{cr}\text { lain } & \text { terkait } \\ \text { adalah } & \text { Laporan } \\ \text { Realisasi } & \text { Pelaksanaan }\end{array}$ APBDesa belum diinformasikan kepada masyarakat secara tertulis dan belum ditayangkan pada media informasi yang mudah diakses oleh masyarakat.

\section{Kesimpulan, Keterbatasan dan Saran}

Dari hasil penelitian atas sistem pengelolaan dan sistem pengendalian keuangan desa pada Kecamatan Cilongok diperoleh kesimpulan bahwa secara umum pengelolaan keuangan desa pada Kecamatan Cilongok sudah cukup baik, namun masih terdapat kekurangan terutama pada tahap penatausahaan, pelaporan dan pertanggungjawaban.Perangkat Pengelola Keuangan Desa secara umum sudah menjalankan tugas dan fungsinya. Kepala Desa sebagai pemegang kekuasaan pengelola keuangan desa dibantu oleh Pelaksana Teknis Pengelolaan Keuangan Desa. Namun, belum seluruh Bendahara Desa dijabat oleh staf pada urusan keuangan.Tahapan perencanaan secara umum telah dilaksanakan dengan baik.Sekretaris Desa seluruhnya telah menyusun Rancangan Peraturan Desa tentang APBDesa berdasarkan RKP Desa tahun berkenaan dan disampaikan kepada Kepala Desa. Kepala Desa menyampaikan Rancangan Peraturan Desa tentang APBDesa kepada BPD untuk dibahas dan disepakati bersama.Namun, APBDesa dirasa masih belum berisi kebutuhan desa secara riil. APBDesa belum disusun berdasarkan hasil pengkajian keadaan desa dan belum memperhatikan batasan waktu penyusunan APBDesa sesuai peraturan perundangundangan.Tahap pelaksanaan secara umum sudah dijalankan dengan cukup baik. Mekanisme penerimaan dilaksanakan melalui rekening kas desa. Rekening kas desa ditetapkan pada Bank Jateng sesuai ketentuan peraturan Bupati Banyumas. Namun, pemerintah desa di Kecamatan Cilongok masih belum dapat melakukan konversi ke dalam nilai uang (rupiah) atas penerimaan swadaya, sumbangan yang berupa tenaga atau barang. Dalam pelaksanaan belanja pemerintah Kabupaten Cilongok sudah menjalankan mekanisme SPP beserta proses verifikasinya. Sudah memiliki Peraturan Bupati tentang Pengadaan Barang dan Jasa di Desa. Pada tahap penatausahaan, Bendahara Desa masih kurang tertib dalam melaksanakan penatausahaan pengelolaan keuangan desa. Pencatatan penerimaan dan pengeluaran desa baru dilaksanakan dengan menggunakan buku kas umum. Bendahara Desa juga belum melakukan penutupan pembukuan setiap akhir bulan secara tertib, dan belum menyampaikan laporan pertanggungjawaban kepada Kepala Desa. Pada tahap pelaporan, secara umum desa belum tertib dalam menyampaikan laporan realisasi pelaksanaan APBDesa semester pertama maupun semester kedua. Pada tahap pertanggungjawaban, Kepala Desa belum menyampaikan Laporan Pertanggungjawaban Realisasi Pelaksanaan 
APBDesa secara tepat waktu. Pemerintah Desa belum mampu menyusun Laporan Kekayaan Milik Desa karena kurangnya pemahaman sumber daya manusia pada tingkat desa.

Penelitian ini memiliki keterbatasan antara lain tahapan pengelolaan dana desa yang diteliti hanya pada tahap perencanaan, pelaksanaan, sampai dengan pertanggungjawaban pada tingkat desa, tidak membahas pengelolaan dana desa di tingkat Kecamatan, Kabupaten, maupun proses alokasi dan pertanggungjawaban dana di Kementerian Keuangan.Periode pengelolaan keuangan desa yang diteliti hanya terbatas untuk Tahun 2015 dan 2016 tidak meliputi kegiatan perencanaan jangka panjang maupun perencanaan jangka menengah. Selain itu, penelitian ini tidak membahas dampak dari penggunaan keuangan desa serta tidak membahas efektivitas dan keberhasilan dari penggunaan dana desa.

Berdasarkan hasil penelitian tersebut, untuk peningkatan pengelolaan keuangan desa, maka peneliti menyarankan untuk meningkatkan kemampuan Perangkat Pengelola Keuangan Desa mulai dari Kepala Desa, Sekretaris Desa, Kepala Seksi/Kepala Urusan (Kaur), dan Bendahara Desa perlu diberikan pelatihan terkait pengelolaan keuangan desa mulai dari tahap perencanaan, pelaksanaan, penatausahaan, pelaporan dan pertanggungjawaban secara menyeluruh, serta perencanaan dan penyusunan APBDesa agar lebih memperhatikan kebutuhan masyarakat desa.

\section{Daftar Referensi}

Azwardi, A. (2014). Efektifitas Alokasi Dana Desa (ADD) dan Kemiskinan di Provinsi Sumatera Selatan. Jurnal Ekonomi Pembangunan, 12(1), 29-41.

Bastian, I. (2015). Akuntansi untuk Kecamatan dan Desa. Erlangga: Jakarta.

Bungin, B. (2007). Penelitian kualitatif: komunikasi, ekonomi, kebijakan publik, dan ilmu sosial lainnya. Kencana.

Desa, L. H. K. P. K. Alokasi Dana Desa dan Dana Desa. 2015. Jakarta: Komisi Pemberantasan Korupsi.

Gilardi, F. (2001, September). Principal-agent models go to Europe: Independent regulatory agencies as ultimate step of delegation. In ECPR General Conference, Canterbury (UK)(pp. 6-8).

Indonesia, I. A., \&Publik, K. A. S. (2015). Pedoman Asistensi Akuntansi Keuangan Desa. Jakarta: IAI.

Indonesia, P. P. R. (2014). Peraturan Pemerintah Republik Indonesia Nomor 43 Tahun 2014 tentang Peraturan Pelaksaan Undangundang Nomor 6 Tahun 2014 Tentang Desa. Jakarta: Sekretariat Negara.

Indonesia, R. (2005). Peraturan Pemerintah Republik Indonesia Nomor 72 Tahun 2005 Tentang Desa. Jakarta: Sekretariat Negara.

Indonesia, R. (2014). Undang-undangNomor 6 tahun 2014 tentangDesa. Jakarta: Sekretariat Negara.

Jensen, M. C., \& Meckling, W. H. (1976). Theory of the firm: Managerial behavior, agency costs and ownership structure. Journal of financial economics, 3(4), 305-360.

Keuangan, B. P., \& Pembangunan, R. I. (2015). Petunjuk Pelaksanaan Bimbingan dan Konsultasi Pengelolaan Keuangan Desa. BPKP RI, Jakarta.

Moe, T. M. (1984). The new economics of organization. American journal of political science, 28(4), 739-777.

Moleong, L. (2013). J. 2007. Metodologi penelitian kualitatif, 4-10.

Negara, K. P. A., \& INDONESIA, R. (2004). Pedoman Umum Penyusunan Indeks Kepuasan Masyarakat Unit Pelayanan Instansi Pemerintah.

Putra, C. K. (2013). Pengelolaan Alokasi Dana Desa Dalam Pemberdayaan Masyarakat Desa (Studi Pada Desa Wonorejo Kecamatan Singosari Kabupaten Malang). Jurnal Administrasi Publik, 1(6), 1203-1212.

Republik Indonesia, 2008. Peraturan Pemerintah Nomor 60 Tahun 2014 tentang Dana Desa yang Bersumber dari Anggaran Pendapatan dan Belanja Negara, Jakarta.

Republik Indonesia, 2014. Peraturan Menteri Dalam Negeri Nomor 113 Tahun 2014 tentang Pengelolaan Keuangan Desa, Jakarta. 
JRAP (Jurnal Riset Akuntansi dan Perpajakan) Vol.6 No.1, Juni 2019, hal 25-37

ISSN 2460-2132

Republik Indonesia, 2015. Peraturan Pemerintah Nomor 22 Tahun 2015 tentang Perubahan Peraturan Pemerintah Nomor 43 Tahun 2014, Jakarta.

Riyanto, T. (2015). Akuntabilitas Finansial Dalam Pengelolaan Alokasi Dana Desa (Add) di Kantor Desa Perangat Selatan Kecamatan Marangkayu Kabupaten Kutai Kartanegara. Ejournal Administrasi Negara, 3(1), 199-130.

Setyoko, P. I. (2011). Akuntabilitas Administrasi Keuangan Program Alokasi Dana Desa (ADD). JIANA (JurnalImuAdministrasi Negara), 11(01).

Strøm, K. (2000). Delegation and accountability in parliamentary democracies. European journal of political research, 37(3), 261-290.
Sugiyono, P. (2005). Memahamipenelitiankualitatif. Bandung: Alfabeta.

Warsono, H., \&Ruksamin, D. (2014). The Obstacles of Implementation of Village Allocation Fund Program in the North Konawe Southeast Sulawesi. J. Mgmt. \& Sustainability, 4, 175.

Yin, R. K. (2002). Studi kasus: desain dan metode. Jakarta: PT. Raja Grafindo Perkasa.

www.keuangandesa.com/category/presentasi/ keuangan-dan-aset-desa

www.djpk.kemenkeu.go.id

www.kpk.go.id 
